\title{
Modeling Consumer Price Index: An Empirical Analysis Using Expert Modeler
}

\author{
Chaitanya Singla ${ }^{1}$, Pradeepta Kumar Sarangi ${ }^{1 *}$, Sunny Singh ${ }^{1}$, \\ Ashok Kumar Sahoo ${ }^{2}$ \\ ${ }^{1}$ Chitkara University Institute of Engineering and Technology, \\ Chitkara University, Punjab-140401, India \\ ${ }^{2}$ Graphic Era Hill University, Dehradun-248171, India
}

\begin{abstract}
Consumer price index (CPI) a popular economic indicator for India that represents the prices paid by customers for goods and services consumedby them.CPI is often used as an economic indicator that reflects the change in prices of goods and services over a period of time. In this work an attempt has been made to develop a forecasting model for India's CPI for the period of May to December 2018. The data used in this work is the all-India CPI data for the period January 2013 - April 2018. SPSS Expert Modeler method has been used to fit the models and analyzing the data.
\end{abstract}

Key Words: Consumer price index, Time series forecasting, Expert modeler, ARIMA model

\section{INTRODUCTION}

Time series forecasting has a great importance in future planning and business decision making. It is an important tool for economic analysis. Starting from weather forecasting, stock market prediction, sales forecasting etc. everywhere the historical data needs to be analyzed. It not only gives a future value for that that but also helps the higher management to take timely decision. Many researches have been conducted to analyze the applicability of various time series methods in different dimensions. One such area is forecasting consumer price index. Singh \& Sarangi (2009), Sarangi \& Singh (2009), Sarangi \& Sarangi (2010), Sarangi \& Sarangi (2010), Gupta \& Sarangi (2012), Singh \& Sarangi (2014), Sarangi \& Pant (2014), Sarangi (2010).

$\mathrm{CPI}$ is often used as an economic indicator that reflects the change in prices of goods and servicesfor a specific period of time. CPI reflects the change in prices over a period of time and a key measure for inflation. It can be said that CPI acts a very critical performance grade of the government of the day Singh et al. (2018). It not only provides information about the inflation in the country but also is used to adjust pensions and social security benefits. Nobert et al. (2016). The CPI data mainly consists of historical data over a long period and contains many variables related to consumer goods and services. A large number of researchers have worked on it and still working on it to present better and better models $\&$ methods for time series forecasting. Some of them

Journal of Technology Management for Growing Economies Vol. 10 , No. 1 April, 2019 pp. $43-50$

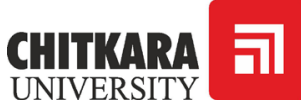

CO2019 by Chitkara University. All Rights Reserved. 
Singla, C.

Sarangi, P. K.

Singh, $\mathrm{S}$.

Sahoo, A. K. are cited here. Cryer and Chan (2008), Brocwell and Davis (2002), Box and Jenkins (1976), Montgomery et al. (2008).

The main components in the CPI in India are food and beverages (45.86\%) and miscellaneous categories account for $28.32 \%$ which include transportation and communication health and education, housing sector, fuel and light, clothing and footwear etc. Iqbal and Naveed (2016).

There are a number of forecasting methods exist. Some of them which are very popular are moving average method, Exponential smoothing method, Holt's linear trend and seasonal method, ARIMA method and Neural network method. Here we present some research works where similar techniques have been reported.

Habimana Norbert et al. (2016) presents a paper on Modeling and Forecasting Consumer Price Index. The fundamental target of their experiment was to model the dynamic of CPI and to estimate its future qualities in short term. The authors have used Box and Jenkins method utilizing three steps like Model Identification, Parameter Estimation and Diagnostic Checking and using ARIMA $(4,1,6)$ they have made precise prediction for one year in advance i.e 2016.

The study conducted by Iqbal et al. (2016) using time series dataanalyze the future prediction of various ARIMA models with Box-Jenkins approach is used for forecasting. The authors have used the quarterly data for empirical analysis for the period of 1970 to 2006 for Pakistan.

In another experiment, Weng Dongdong (2010) has performed an experiment on the correlation function and the partial correlation function of consumer price index. The author has used ARIMA $(12,1,12)$ model to test residual serial autocorrelation. Finally,the author has made a short-term estimation on monthly CPI.

In their work, Admas et al. (2014) present a time series model to fit the CPI in Nigeria's Inflation rate between 1980 and 2010. The authors have provided five years forecasted value for the expected CPI in Nigeria. The authors have used ARIMA models.

A detailed study on the advantages and disadvantages of various forecasting methods is done by Qizhi et al. (2012). The authors have made anempirical comparison between various methods like ARIMA-GARCH, ARIMA, neural networks, median method of autoregressive model, least squares method of autoregressive model and exponential smoothing.

Another model to forecast CPI through ANN is reported by M. Akin (1999). The author has used leading economic indicator data like Producer

Journal of Technology Management for Growing Economies, Volume 10, Number 1, April 2019 
Price Index (PPI) and change in money supply M2 were used for developing the neural network.

Salzano and Colander (2007) proposed two models: one is a linear model and another one is a non-linear model. The authors have made acomparison of these two models to forecast the CPI.

In another work, the power of artificial neural network models as forecasting tools for monthly inflation rates for 28 OECD countries was verified by Choudhary and Haider (2008).

Linear and neural network-based models is applied by McAdam and McNelis (2005). The authors have forecasted inflation based on Phillips-curve formulations in the USA, Japan and the euro area.

\section{OBJECTIVE}

The objective of this work is to forecast the India's CPI (for eight products: Cereals and products, Meat and fish, Egg, Milk and Products, Oils and fats, Fruits, Vegetables, Pulses and products) for the period May to December 2018.

\section{DATA}

The data used in this work is the all India CPI data of India for the period of January 2013 to April 2018.

\section{IMPLEMENTATION DESIGN AND MODEL SUMMARY}

The forecasting has been done using the Expert Modeler of SPSS. The software has automatically taken care of the nature of data and has selected the appropriate model. The model type selected by the software based on the nature of the data is given in Table 1 .

Table 1: Model description

\begin{tabular}{|l|l|l|l|}
\hline \multicolumn{2}{|l|}{} & Model Type \\
\hline \multirow{4}{*}{} & Cereals and products & Model_1 & Holt \\
\cline { 2 - 4 } & Meat and fish & Model_2 & Winters'Additive \\
\cline { 2 - 5 } & Egg & Model_3 & Winters'Additive \\
\cline { 2 - 5 } & Milk and products & Model_4 & Holt \\
\cline { 2 - 5 } & Oils and fats & Model_5 & Winters'Additive \\
\cline { 2 - 4 } & Fruits & Model_6 & Winters' Additive \\
\cline { 2 - 4 } & Vegetables & Model_7 & Simple Seasonal \\
\cline { 2 - 4 } & Pulses and products & Model_8 & ARIMA $(1,1,0)(0,0,0)$ \\
\hline
\end{tabular}

Journal of Technology Management for Growing Economies, Volume 10, Number 1, April 2019 
Singla, C.

Sarangi, P. K.

Singh, S.

Sahoo, A. K.

Table 2: Model Fit

\begin{tabular}{|l|r|r|r|r|}
\hline Fit Statistic & \multicolumn{1}{|c|}{ Mean } & \multicolumn{1}{c|}{ SE } & \multicolumn{1}{c|}{ Minimum } & \multicolumn{1}{c|}{ Maximum } \\
\hline Stationary R-squared & .492 & .224 & .133 & .677 \\
\hline R-squared & .976 & .038 & .887 & .999 \\
\hline RMSE & 1.772 & 2.100 & .302 & 6.589 \\
\hline MAPE & .958 & 1.125 & .196 & 3.606 \\
\hline MaxAPE & 4.021 & 4.360 & .584 & 13.524 \\
\hline MAE & 1.317 & 1.657 & .248 & 5.233 \\
\hline MaxAE & 5.776 & 6.611 & .657 & 19.664 \\
\hline Normalized BIC & .257 & 2.144 & -2.267 & 3.901 \\
\hline
\end{tabular}

Table 3: Model Statistics

\begin{tabular}{|c|c|c|c|c|c|c|}
\hline \multirow{2}{*}{ Model } & \multirow{2}{*}{$\begin{array}{c}\text { Number } \\
\text { of Pre- } \\
\text { dictors }\end{array}$} & \multirow{2}{*}{$\begin{array}{c}\begin{array}{c}\text { Model Fit } \\
\text { statistics }\end{array} \\
\text { Stationary } \\
\text { R-squared }\end{array}$} & \multicolumn{3}{|c|}{ Ljung-Box Q(18) } & \multirow{2}{*}{$\begin{array}{c}\text { Number } \\
\text { of } \\
\text { Outliers }\end{array}$} \\
\hline & & & Statistics & DF & Sig. & \\
\hline Cereals and products-Model_1 & 0 & .144 & 16.220 & 16 & .438 & 0 \\
\hline Meat and fish-Model_2 & 0 & .639 & 21.521 & 15 & .121 & 0 \\
\hline Egg-Model_3 & 0 & .551 & 12.958 & 15 & .606 & 0 \\
\hline Milk and products-Model_4 & 0 & .133 & 16.357 & 16 & .428 & 0 \\
\hline Oils and fats-Model_5 & 0 & .677 & 35.027 & 15 & .002 & 0 \\
\hline Fruits-Model_6 & 0 & .639 & 30.663 & 15 & .010 & 0 \\
\hline Vegetables-Model_7 & 0 & .626 & 24.786 & 16 & .074 & 0 \\
\hline Pulses and products-Model_8 & 0 & .526 & 18.669 & 17 & .348 & 0 \\
\hline
\end{tabular}

Table 4(a): Exponential Smoothing Model Parameters

\begin{tabular}{|l|l|l|r|r|r|r|}
\hline \multicolumn{2}{|l|}{ Model } & Estimate & \multicolumn{1}{c|}{ SE } & \multicolumn{1}{c|}{ t } & \multicolumn{1}{c|}{ Sig. } \\
\hline \multirow{2}{*}{$\begin{array}{l}\text { Cereals and } \\
\text { products-Model_1 }\end{array}$} & $\begin{array}{l}\text { No Trans- } \\
\text { formation }\end{array}$ & Alpha (Level) & 1.000 & .116 & 8.591 & .000 \\
\cline { 3 - 7 } & Gamma (Trend) & .400 & .134 & 2.994 & .004 \\
\hline \multirow{3}{*}{$\begin{array}{l}\text { Meat and } \\
\text { fish-Model_2 }\end{array}$} & \multirow{2}{*}{$\begin{array}{l}\text { No Trans- } \\
\text { formation }\end{array}$} & Alpha (Level) & .999 & .124 & 8.084 & .000 \\
\cline { 3 - 7 } & Gamma (Trend) & $1.222 \mathrm{E}-5$ & .046 & .000 & 1.000 \\
\cline { 3 - 7 } & Delta (Season) & .999 & 92.121 & .011 & .991 \\
\hline \multirow{3}{*}{ Egg-Model_3 } & \multirow{2}{*}{$\begin{array}{l}\text { No Trans- } \\
\text { formation }\end{array}$} & Alpha (Level) & 1.000 & .130 & 7.709 & .000 \\
\cline { 3 - 7 } & Gamma (Trend) & .001 & .037 & .017 & .986 \\
\cline { 3 - 7 } & Delta (Season) & .001 & 8605.314 & $1.162 \mathrm{E}-7$ & 1.000 \\
\hline \multirow{2}{*}{$\begin{array}{l}\text { Milk and } \\
\text { products-Model_4 }\end{array}$} & $\begin{array}{l}\text { No Trans- } \\
\text { formation }\end{array}$ & Alpha (Level) & 1.000 & .123 & 8.148 & .000 \\
\cline { 3 - 7 } & Gamma (Trend) & .500 & .160 & 3.118 & .003 \\
\hline
\end{tabular}

Journal of Technology Management for Growing Economies, Volume 10, Number 1, April 2019 
Table 4(b): Exponential Smoothing Model Parameters

\begin{tabular}{|l|l|l|r|r|r|r|}
\hline Model & Estimate & \multicolumn{1}{c|}{ SE } & \multicolumn{1}{c|}{ t } & \multicolumn{1}{c|}{ Sig. } \\
\hline & & Gamma (Trend) & .500 & .160 & 3.118 & .003 \\
\hline \multirow{2}{*}{$\begin{array}{l}\text { Oils and } \\
\text { fats-Model_5 }\end{array}$} & $\begin{array}{l}\text { No } \\
\text { Transfor- } \\
\text { mation }\end{array}$ & Alpha (Level) & 1.000 & .129 & 7.730 & .000 \\
\cline { 3 - 7 } & Gamma (Trend) & .001 & .017 & .060 & .952 \\
\cline { 2 - 7 } & Delta (Season) & .001 & 992.672 & $1.007 \mathrm{E}-6$ & 1.000 \\
\hline \multirow{2}{*}{$\begin{array}{l}\text { Fruits- } \\
\text { Model_6 }\end{array}$} & $\begin{array}{l}\text { No } \\
\text { Transfor- } \\
\text { mation }\end{array}$ & Alpha (Level) & 1.000 & .130 & 7.677 & .000 \\
\cline { 3 - 7 } & Gamma (Trend) & .001 & .016 & .061 & .952 \\
\cline { 2 - 7 } & Delta (Season) & .001 & 5738.845 & $1.743 \mathrm{E}-7$ & 1.000 \\
\hline \multirow{2}{*}{$\begin{array}{l}\text { Vegetables- } \\
\text { Model_7 }\end{array}$} & $\begin{array}{l}\text { No } \\
\text { Transfor- } \\
\text { mation }\end{array}$ & Alpha (Level) & .999 & .128 & 7.832 & .000 \\
\cline { 3 - 7 } & Delta (Season) & 1.000 & 130.574 & .008 & .994 \\
\hline
\end{tabular}

Table 5: ARIMA Model Parameters

\begin{tabular}{|l|l|l|l|l|r|c|c|c|}
\hline \multicolumn{3}{|c|}{} & Estimate & SE & t & Sig. \\
\hline $\begin{array}{l}\text { Pulses and } \\
\text { products- } \\
\text { Model_8 }\end{array}$ & $\begin{array}{l}\text { Pulses and } \\
\text { products }\end{array}$ & $\begin{array}{l}\text { Natural } \\
\text { Logarithm }\end{array}$ & AR & Lag 1 & .720 & .087 & 8.282 & .000 \\
\cline { 5 - 9 } & & Difference & 1 & & & \\
\hline
\end{tabular}

Table 6: Forecast

\begin{tabular}{|l|c|c|c|c|c|c|c|c|}
\hline \multicolumn{1}{|c|}{ Model } & $\begin{array}{c}\text { May } \\
\mathbf{2 0 1 8}\end{array}$ & $\begin{array}{c}\text { Jun } \\
\mathbf{2 0 1 8}\end{array}$ & $\begin{array}{c}\text { Jul } \\
\mathbf{2 0 1 8}\end{array}$ & $\begin{array}{c}\text { Aug } \\
\mathbf{2 0 1 8}\end{array}$ & $\begin{array}{c}\text { Sep } \\
\mathbf{2 0 1 8}\end{array}$ & $\begin{array}{c}\text { Oct } \\
\mathbf{2 0 1 8}\end{array}$ & $\begin{array}{c}\text { Nov } \\
\mathbf{2 0 1 8}\end{array}$ & $\begin{array}{c}\text { Dec } \\
\mathbf{2 0 1 8}\end{array}$ \\
\hline $\begin{array}{l}\text { Cereals and } \\
\text { products-Model_1 }\end{array}$ & 136.6 & 136.8 & 137.0 & 137.2 & 137.4 & 137.6 & 137.8 & 138.0 \\
\hline $\begin{array}{l}\text { Meat and fish- } \\
\text { Model_2 }\end{array}$ & 146.6 & 149.4 & 150.2 & 149.4 & 148.5 & 148.3 & 148.2 & 148.7 \\
\hline Egg-Model_3 & 134.0 & 137.3 & 139.1 & 138.6 & 138.4 & 138.9 & 143.8 & 146.6 \\
\hline $\begin{array}{l}\text { Milk and products- } \\
\text { Model_4 }\end{array}$ & 141.9 & 142.2 & 142.4 & 142.7 & 143.0 & 143.3 & 143.5 & 143.8 \\
\hline $\begin{array}{l}\text { Oils and fats- } \\
\text { Model_5 }\end{array}$ & 121.1 & 121.6 & 121.8 & 122.0 & 122.4 & 123.0 & 123.6 & 124.1 \\
\hline Fruits-Model_6 & 153.2 & 154.0 & 155.6 & 155.9 & 152.9 & 152.8 & 153.3 & 152.5 \\
\hline $\begin{array}{l}\text { Vegetables- } \\
\text { Model_7 }\end{array}$ & 136.2 & 146.5 & 161.8 & 169.4 & 166.8 & 168.7 & 170.2 & 152.2 \\
\hline $\begin{array}{l}\text { Pulses and } \\
\text { products-Model_8 }\end{array}$ & 122.7 & 122.2 & 121.9 & 121.7 & 121.6 & 121.6 & 121.7 & 121.8 \\
\hline
\end{tabular}

Journal of Technology Management for Growing Economies, Volume 10, Number 1, April 2019 
Singla, C.

Sarangi, P. K.

Singh, S.

Sahoo, A. K.

48
The graphs produced by SPSS for each item showing the observed values, fit values and forecasted values are given in Figure 1.
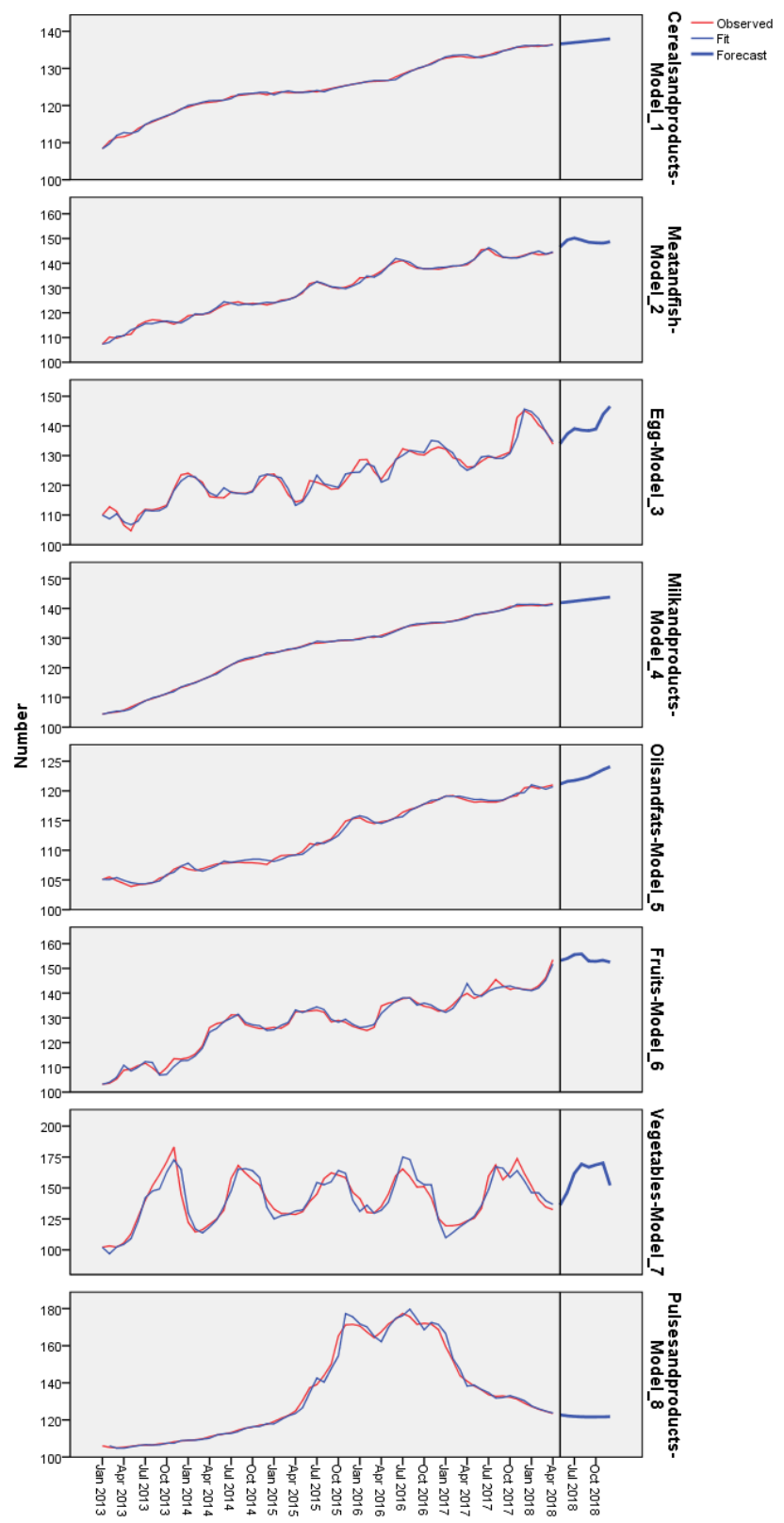

Date

Figure 1: Graphical representation of observed, fit and forecasted values 
From the graphs above, the following interpretations are drawn:

(i) The CPI for Cereals and products will increase by $1.024 \%$ in December in comparison to May 2018.

(ii) The CPI for Meat \& Fish will increase by $1.432 \%$ in December in comparison to May 2018.

(iii) The CPI for Egg will increase by $9.402 \%$ in December in comparison to May 2018.

(iv) The CPI for Milk and products will increase by $1.338 \%$ in December in comparison to May 2018.

(v) The CPI for Oils and fats will increase by $2.477 \%$ in December in comparison to May 2018.

(vi) The CPI for Fruits will decrease by $0.456 \%$ in December in comparison to May 2018.

(vii) The CPI for Vegetables will increase by $11.747 \%$ in December in comparison to May 2018.

(viii)The CPI for Pulses and products will decrease by $0.733 \%$ in December in comparison to May 2018.

\section{CONCLUSION}

This study concludes that in the near future (till December 2018) there will be a slight increase in some of the products under study such as Cereals and products, Meat \& Fish, Egg, Milk and products, Oils and fats and Vegetables. Whereas prices for products like Fruits and Pulses will likely to decrease.

An increase in CPI indicates that there will be an increase in the prices of these items resulting a house hold will have to pay more to maintain the same standard of living and the decrease in CPI will result in a decrease in price for the other items like fruits and pulses.

\section{DECLARATION}

The outcome of this study is purely academic and may only be considered for study and research purposes. The actual situation can only be verified with time.

\section{REFERENCES}

Adams, S.O., Awujola, A., and Alumgudu, A.I. (2014) "Modeling Nigeria's Consumer Price Index Using Arima Model", International Journal of Development and Economic Sustainability, 2(2), pp. 37-47.

Aiken, M. (1999) "Using a Neural Network to Forecast Inflation", Journal of Industrial Management \& Data Systems, 99(7), pp. 296-301. https://doi.org/10.1108/02635579910291984

Box,G.E.P. and Jenkins, G. M. (1976) “Time Series Analysis: Forecasting and Control”, San Fransisco: Holden-Day.

Journal of Technology Management for Growing Economies, Volume 10, Number 1, April 2019 
Singla, C.

Sarangi, P. K.

Singh, $\mathrm{S}$.

Sahoo, A. K.
Brocwell,P.J. and Davis, R. A. (2002) "Introduction to Time Series and Forecasting", New York: Springer.

Choudhary, A. and Haider, A. (2008) "Neural Network Models for Inflation Forecasting: An Appraisal", Applied Economics, 44(20). https://doi.org/10.1080/00036846.2011.566190.

Cryer J.D. and Chan, K.S. (2008) "Time Series Analysis with Application in R", New York, Springer.

Dongdong, W. (2010) "The Consumer Price Index Forecast Based on ARIMA Model”, WASE International Conference on Information Engineering. Publisher: IEEE. https://doi.org/10.1109/ICIE.2010.79,

Gupta, A. and Sarangi, P.K. (2012) "Electrical Load Forecasting using Genetic Algorithm based Back-propagation Method", ARPN Journal of Engineering and Applied Sciences, 7(8), pp. 1017-1020.

He, Q., Shen, H. and Tong, Z. (2012) "Investigation of Inflation Forecasting", Applied Mathematics \& Information Sciences An International Journal, 6(3): 649-655.

Iqbal, M. and Naveed, A. (2016) "Forecasting Inflation: Autoregressive Integrated Moving Average Model", European Scientific Journal, 12(1), pp. 83-91.

McAdam, P. and McNelis, P. (2005) "Forecasting Inflation with Thick Models and Neural Networks", Economic Modeling, 22(5), pp. 848-867. https://doi.org/10.1016/j.econmod.2005.06.002.

Montgomery, D.C., Jennings,C.L. and Kulahci, M. (2008) "Introduction to Time Series Analysis and Forecasting", New York: John Wiley \& Sons.

Norbert, H., Wanjoya, A. and Waititu, A. (2016) "Modeling and Forecasting Consumer Price Index (Case of Rwanda)", American Journal of Theoretical and Applied Statistics, 5(3), pp. 101-107. https://doi.org/10.11648/j.ajtas.20160503.14.

Salzano, M. and Colander, D. (2007) "Complexity Hints for Economic Policy", Milan: Springer.

Sarangi, P. K. (2010) "Innovations in Management Science", Global Research Publications: 283-298, edited by Dr. Prasanta Sarangi, ISSN/ISBN No. 8189630075, 9788189630072.

Sarangi, P.K., and Sarangi, P. (2010) "Load Forecasting using Artificial Neural Network: Performance evaluation with different numbers of hidden neurons", IUP Journal of Information Technology, 6 (1), pp. 34-42.

Sarangi, P.K., and Sarangi, P. (2010) "Short-Term Load Forecasting Using Neural Network Technology", IUP Journal of Computer Sciences, 4 (2), pp. 15-23.

Sarangi, P.K., Singh, N., Chauhan, R.K., and Singh, R. (2009) "Short Term Load Forecasting using Neuro Genetic Hybrid Approach: Results Analysis with different Network Architectures", Journal of Theoretical and Applied Information Technology, 5(8), pp. 109-116.

Sarangi, P.K.,Bano, S. and Pant, M. (2014) "Future Trend in Indian Automobile Industry: A Statistical Approach", Apeejay-Journal of Management Sciences and Technology, 1(2), pp. 28-32.

Singh, N., Sarangi, P.K., Chauhan, R.K. and Singh, R. (2009) "Short Term Load Forecasting using Artificial Neural Network: A Comparison with Genetic Algorithm Implementation", Journal of Engineering and Applied Sciences, 4 (9), pp. 88-93.

https://doi.org/10.1109/ICNGIS.2016.7854003

Singh, S. and Sarangi, P.K. (2014) "Growth Rate of Indian Spices Exports: Past Trend and Future Prospects", Apeejay - Journal of Management Sciences and Technology, 2 (1)pp. 29-34.

Sinha, D,Sarangi, P., Sinha, S. and Sharma, M. (2018) "Forecasting Consumer Price Index using Neural Network Models". $3^{\text {rd }}$ Conference on Innovative Practices in Operations Management \& Information technology, Published in book of proceedings, ISBN 978-9384562-11-3:84-93.

Journal of Technology Management for Growing Economies, Volume 10, Number 1, April 2019 